\title{
The Analysis Critical-Thinking Skills of Junior High School Students on Geoscience
}

\author{
Anggraeni Rusmia Putri1, Eko Hariyono², Erman ${ }^{3}$ \\ 1,2,3 State University of Surabaya, Surabaya, Indonesia
}

\begin{tabular}{|c|c|}
\hline (A) Check for updates open $\partial_{\text {Access }}$ @c) (1) ( & DOI : https://doi.org/10.46245/ijorer.v2i3.102 \\
\hline Sections Info & ABSTRACT \\
\hline $\begin{array}{l}\text { Article history: } \\
\text { Submitted: February 20, } 2021 \\
\text { Final Revised: April 09, } 2021 \\
\text { Accepted: April 18, 2021 } \\
\text { Published Online: May 31, } 2021 \\
\text { Keywords: } \\
\text { Critical-Thinking } \\
\text { Geoscience Concept } \\
\text { Junior High School } \\
\end{array}$ & $\begin{array}{l}\text { This research aims to analyze the critical-thinking skill of the junior high } \\
\text { school student in Mojokerto. This research describes students geoscience } \\
\text { conception by using question instruments related to students' critical-thinking } \\
\text { skills. The method that used in this research was pre-experimental design with } \\
\text { one-shot case study design and descriptive quantitative approach. The test is } \\
\text { done online via google form. The question instrument contains } 20 \text { questions } \\
\text { related to geoscience concept, disasters, and mitigation materials that have } \\
\text { been validated by a validator. This research involved } 107 \text { students who were } \\
\text { on the } 7 \text { th grade of junior high school in Mojokerto. The results showed that } \\
\text { the analysis related to geoscience knowledge of students got an average of } \\
48.79 \% \text { which was included as very low category, while the critical-thinking } \\
\text { skills got } 43 \% \text { on the interpretation indicator, } 52 \% \text { analysis, } 79 \% \text { evaluation, } \\
40 \% \text { inferential, explanation. } 54 \% \text {, and self regulation } 40 \% \text { with an average } \\
\text { critical-thinking skills of } 51 \% \text { which concluded in the very low category. These } \\
\text { critical-thinking skills must be built, especially in geoscience conceptl. The } \\
\text { accuracy of the analysis of critical-thinking skills in this research only shows } \\
\text { the results in the Mojokerto area. }\end{array}$ \\
\hline
\end{tabular}

\section{INTRODUCTION}

The 21st century is an open flow of globalization that allows information and technology to develop very rapidly which will give an impact to the changing of life aspects (Wijaya et al, 2016). Critical-thinking is an ability or a skill to making concept, applying, analyzing, synthesizing, and evaluating the information that has been collected from the observation process (Abdullah, 2013). Partnership for 21 st Century Skill identifies that critical-thinking skills are one that is needed to prepare the student and working world (Zubaidah, et al., 2015). Critical-thinking includes the individuals skills to make a reason effectively, ask a question and solve the problems, analyze and evaluate, critically describe the decision and the process (Guo, 2016).

In this research, an analyze of the critical-thinking skills of student about geoscience will be carried out. Knowledge of earth science is needed so that people can significantly avoid and cut the damage caused by extreme incident to became the main life disaster (Hariyono, et al, 2016). This is due to the geographic location of Indonesia which is prone to disasters, raise the victims, environmental damage, the losses of properties and impact the psychology (Permenkes, 2014). Some supporting factors in advancing geoscience education in science learning at the level of junior high school according to Anggrayni, et al (2020) among others (1) global sources of profit or income depend on energy source the involved nature were depent on geosciences knowledge; (2) air, soil, minerals, and other resources are a step towards the increasing human population and the global world of global domination today; and (3) recent climate 
change has caused concerns related to sea level rise, drought, forest fires, storm intensity and so on.

The results of research at MTs Al Hidayah Karanggupito show low critical-thinking skills with a percentage of 16,75\% explanation indicators; 33,33\% self-regulation; $41,18 \%$ evaluation; 50,20\% interpretation; 33,33\% inferential, and 62,75\% analysis (Nikmah, et al, 2019). In line with research at junior high school 6 Mojokerto it is categorized as very poor by getting a value interval of less than 62 out of 30 students on earth layer material (Nurdyanto, et al, 2017). Critical-thinking also not only about the skill to think in accordance with the rules of logic and probability, but also the ability to apply the things that already known to real life occasion, which do not depend on the availability of content (Karakoc, 2016).

This research aims to analyze the critical-thinking about geosciences and the ability to contribute in the form of thinking in an effort to minimize disasters. Another function of this analysis is as input for educators in designing appropriate learning to gain critical-thinking skills (Nuryanti, et al, 2018), in the geoscience field on junior high school level.

\section{RESEARCH METHOD \\ General Background}

This research used a pre-experimental design with a one-shot case study design and a descriptive quantitative approach. Descriptive research was a research that aims to describe a state or phenomenon as it is without manipulating the object of research (Sukmadinata, 2015). This research analyzed the reliability of some items based the results of Anates V4 program. The test instrument uses a google form created by researchers which consists of 20 questions about geoscience and opinions on disaster mitigation in a multiple choice form. Multiple choice questions will increase the variety of items that can be used in the assessment, so that the assessment instruments obtained can accommodate broad thinking skills (Hartini \&Sukardjo, 2015).

The basic competencies that support the tools are structured research mastering of the dynamics and earth role as a system in our living, the aspects of understanding of the inter-dependences between the human and the earth, understanding the concept of the layers of the earth, understanding the potential of various natural disasters such as volcanoes and earthquakes in Indonesia, understanding the role of vigilance response against disasters. The research was focused on understanding 3 sub-materials, namely geoscience, natural disasters and their mitigation. In this case, students' knowledge will be measured critical-thinking skills.

\section{Sample / Participants / Group}

Participants in this research involved 107 students who were on the 7th grade of junior high school in Mojokerto, East Java, Indonesia. Samples were taken heterogeneously from all schools in Mojokerto.

\section{Instrument and Procedures}

The criteria for the validation results are described in Table 1 and are calculated by the following formula

$$
\mathrm{R}=\frac{s}{N} \times 100 \%
$$

(Widoyoko, 2017) 


$$
\begin{array}{ll}
\text { Informations: } \\
\mathrm{R} & =\text { Average score } \\
\mathrm{S} & =\text { Number of scores obtained } \\
\mathrm{N} & =\text { Maximum number of scores }
\end{array}
$$

After knowing the validity value of each expert, then combining the results of expert validity and analyzing all expert validators using the following formula

$$
\mathrm{M}_{\mathrm{R}}=\frac{\sum_{R}}{N}
$$

Informations:

(Sudijono, 2017)

$\mathrm{M}_{\mathrm{R}}=$ Average combined score

$\sum R=$ Number of scores obtained

$\mathrm{N}=$ The number of validators

The instrument has validly categorized if the instrument measures the mastery abilities in measured domain (Arifin, 2017). Instrument in this research has valid category after reaching more than $50 \%$ and the instrument is suitable for use (Riduwan, 2014).

Table 1. Criteria of validity coefficient.

\begin{tabular}{ll}
\hline \multicolumn{1}{c}{ Validity coefficient } & \multicolumn{1}{c}{ Criteria } \\
\hline $75 \leq \mathrm{VC} \leq 100$ & Very valid \\
$50 \leq \mathrm{VC}<75$ & Valid \\
$25 \leq \mathrm{VC}<50$ & Enough Valid \\
$0 \leq \mathrm{VC}<25$ & Less Valid \\
\hline
\end{tabular}

(Riduwan, 2014)

Critical-thinking indicators used in this research are according to Facione (2015). Here is a table to present the relevance of critical-thinking skills indicators to question test indicators.

Table 2. The linkage indicators question and critical-thinking skills.

Indicators Critical-Thinking

Interpretation

Analysis

Evaluation

Inferential

Explanation

\section{Indicator Question}

Identifies use the earth's core

Categorizing mitigation efforts before the earthquake

Interpreting disaster prone locations volcanoes based on the image

Categorizing ideas to solve the problem of flooding

Solve the relationship of air pressure in the atmosphere

Trobleshooting tsunami mitigation

Declare benefits of volcano

Inferring the atmospheric layer

Making generalizations of the water cycle

Summarizing information relevant to the flood problem

Identifying the stratosphere layer

Identifying the ozone layer

Identifying flood issues or flood problems

Applying earthquake mitigation solutions 
Self Regulation

Deciding flood prevention strategies

Evaluating self explanatory answers

Evaluate yourself for inferential answers about the water cycle

\section{Data Analysis}

Data analysis using descriptive analysis through techniques percentage for each indicator according to Purwanto (2013). The result of the score will be interpreted with the criteria according to the following table.

$$
\% \text { score }=\frac{\text { average student score }}{\text { maximum student score }} \times 100 \%
$$

Table 3. The Criteria of critical-thinking skills.

\begin{tabular}{cc}
\hline Interval Score & Criteria \\
\hline $86 \%<\mathrm{N}<100 \%$ & Very High \\
$76 \%<\mathrm{N}<85 \%$ & High \\
$60 \%<\mathrm{N}<75 \%$ & Enough \\
$55 \%<\mathrm{N}<59 \%$ & Low \\
$\mathrm{N}<54 \%$ & Very Low \\
\hline
\end{tabular}

(Purwanto, 2013)

\section{RESULTS AND DISCUSSION}

The following are the results of the validation of the question instruments used

Table 4. Expert validation results of instrument test.

\begin{tabular}{lc}
\hline \multicolumn{1}{c}{ Validation Aspects } & Validation Result \\
\hline Question items according to achievement indicators & $97 \%$ \\
The question material being asked is relevant & $92 \%$ \\
The subject matter is clearly formulated & $86 \%$ \\
The working instructions are clear & $89 \%$ \\
Communicative & $95 \%$ \\
Standard common verb & $88 \%$ \\
\hline
\end{tabular}

The validation of the test for critical-thinking was carried out by three junior high school science teachers. The validation aspect shows that each aspect has a very valid level of validity. A good quality test must meet the test requirements, namely validity, reliability, objectivity, practicality, and economics (Arikunto, 2013). Limitations in this research only use validity and reliability requirements. The test is said to be valid if the test can provide appropriate information and can be used to achieve certain goals (Oktanin, 2015). The validity of the items needs to be sought to find out which questions are not feasible and cause low validity (Utomo, 2018). Rationally, the instrument validity can be seen in terms of the suitability of the contents of the questions with the material and indicators (Oktanin, 2015)

The reliability analysis of the instrument was obtained from the results of Anates V4 by getting a value of 0.82 and it was stated that the critical-thinking instrument test that used in the research was reliable with a very high category. The test is said to be reliable 
if the test produces consistent data whenever the test is carried out (Kusairi, 2013). The test is said to be reliable if the test will always give the same results if the test is given to the same group at different times or occasions (Oktanin, 2015). The reliability of multiple choice questions is obtained from product moment correlation result of instrument analyze (Paskalin, 2020). The criteria for the correlation coefficient range from 0.00 to 0.19 are stated to have very low reliability, the r coefficient of the range 0.20 - 0.39 is stated to be low reliable, the range $0.40-0.59$ is declared sufficient, the range $0.60-0.79$ were declared high, and the range $0.80-1.00$ was declared very high (Arikunto, 2013). The conclusion of the item reliability refers to the reliability coefficient criteria of the test with the standard formula $r_{11} 0.70$. If $r_{11}>0.70$; then the questions being tested have high reliability. Conversely, if $r_{11}<0.70$; then the questions tested have low or unreliable reliability (Wijaya, 2019).

The geoscience test score in critical-thinking obtained an average of $48.79 \%$ which is categorized as very low category. Here is a graph of the distribution of critical-thinking skills test scores of junior high school students in Mojokerto.

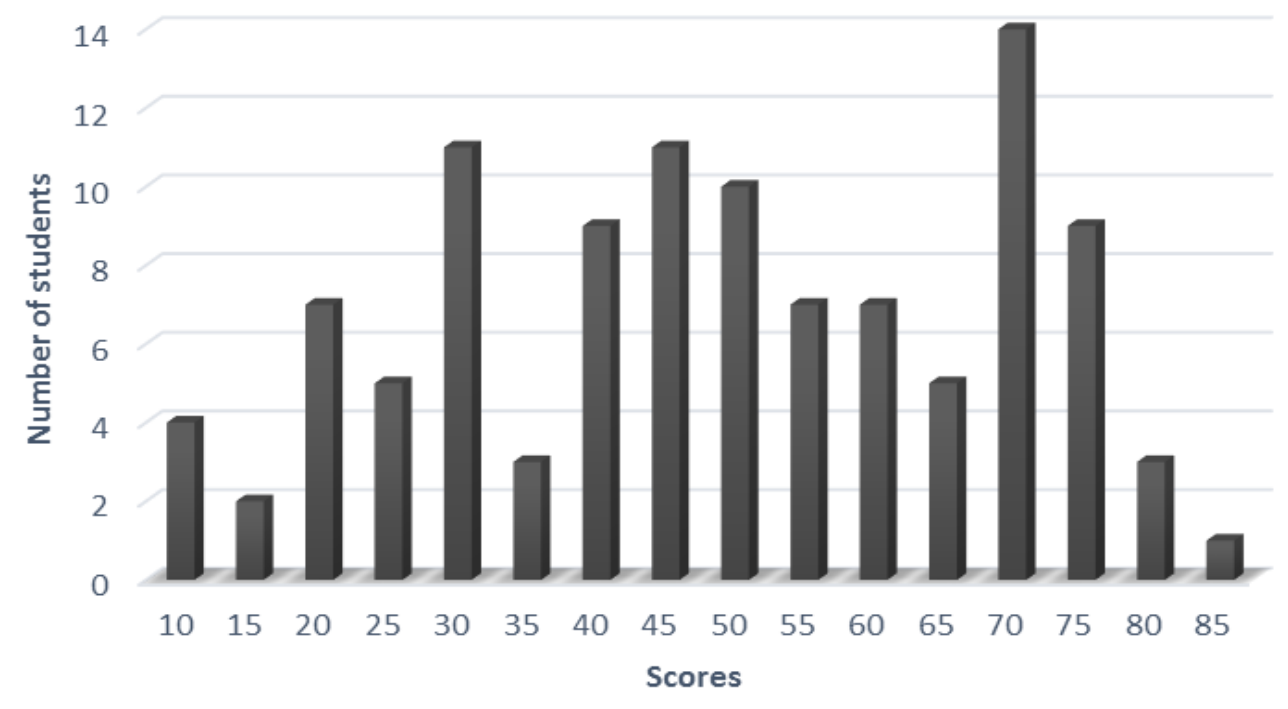

Figure 1. Distribution of geoscience test scores of junior high school students.

The results of the geoscience test score distribution for junior high school students in Mojokerto, the highest average score obtained by students was 70, but the score was not enough to meet the minimum criteria for junior high school science subjects. The minimum completeness criteria are set by the teacher board at a school (Permendikbud, 2016). Based on interviews with teachers in the field of science study, it would be better if the average student had a minimum achievement of 75 so that the geoscience conceptual ability of junior high school students in Mojokerto was included as the category of needing improvement. Hariyono (2016) states that earth science was dominated about theoretical studies and does not focus on the efforts for preparing student awareness about disasters. The learning process should be able to provide a stimulus to students so that they can develop thinking skills such as critical-thinking (Permendikbud, 2013). Education quality, it is necessary to habituate critical-thinking in students in every lesson (Sarjono, 2017). The skill to critically thinking is not only 
needed in the educational process to get high scores, but is also used to help deal with problems in everyday life and careers (Gormley, 2017).

Other factors that can affect students 'scores in answering questions are the students' initial ability, the student's concentration when working on the questions, and the time to work on the questions. There are internal and external factors that affect material achievement (Kallesta, 2017). One of the external factors is that the teacher does not provide motivation and learning resources are less supportive.

Analysis per critical-thinking skills indicators is also presented in graphical form. The following graph is the acquisition of critical-thinking skills scores for junior high school students.

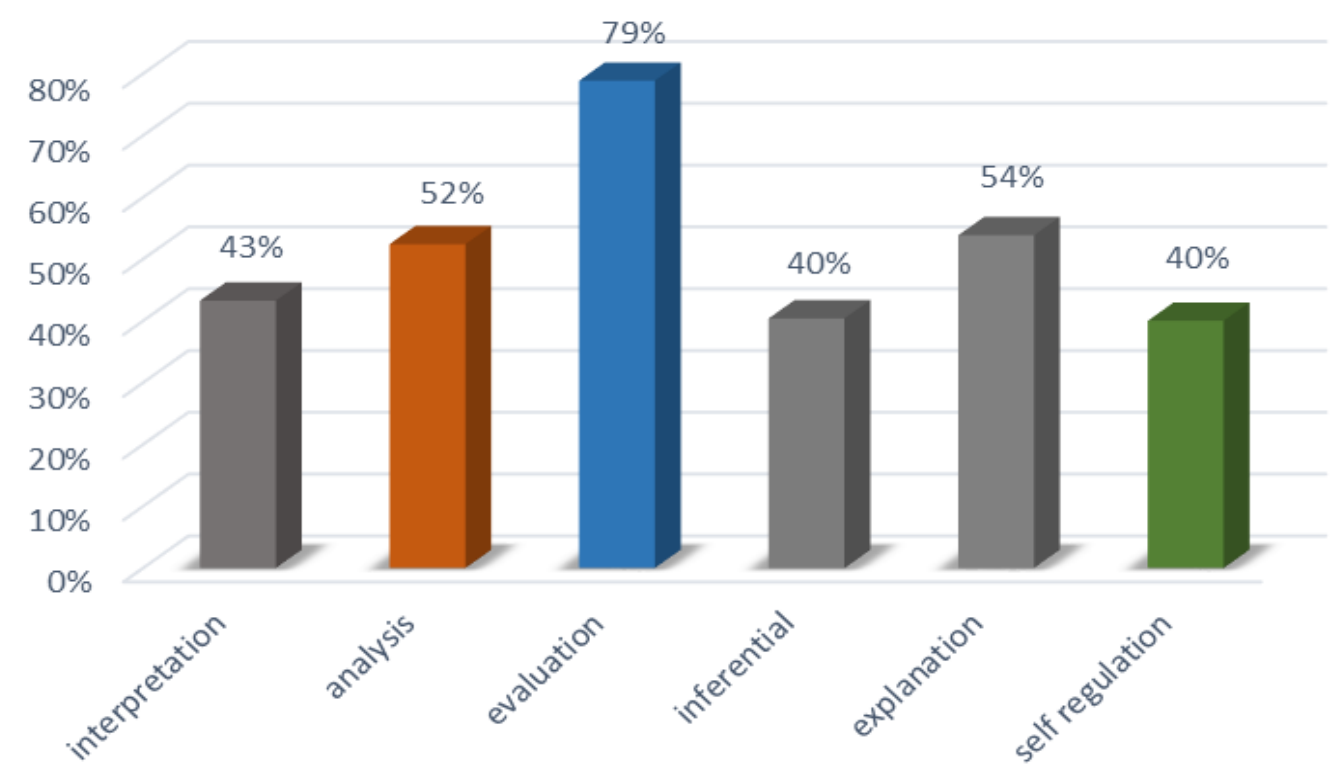

Figure 2. Percentage of critical-thinking indicators.

Displaying the results of critical-thinking skills on the concept of geoscience is categorized in the following explanations:

Table 5. Percentage critical-thinking skills indicator of junior high student.

\begin{tabular}{ccc}
\hline Critical-Thinking Indicator & Percentage (\%) & Criteria \\
\hline Interpretation & 43 & Very Low \\
Analysis & 52 & Very Low \\
Evaluation & 79 & High \\
Inferential & 40 & Very Low \\
Explanation & 54 & Very Low \\
Self Regulation & 40 & Very Low \\
Average & $\mathbf{5 1}$ & Very Low \\
\hline
\end{tabular}

In the results gained from 107 junior high school students in Mojokerto, it is known that students still do not have good critical-thinking skills in the material of geoscience, disasters and their mitigation which obtained an average result of 51 as very low category. Critical-thinking skills are needed, especially in geoscience material for the future, to compete globally. Critical-thinking skills are part of 21st century skills that 
emphasize a discovery-based learning process that focuses on real global problems (Puspita, et al, 2017).

The low ability of students to think critically can occur because the learning applied in schools is still dominated by teachers so that they do not give and prepare a material to train the students's critical-thinking (Nuryanti, et al, 2018). Agree with Mabruroh \& Suhandi (2017) that the learning method applied has not stimulated and fostered students' critical-thinking skills. Yuliati (2013) which states that teaching criticalthinking requires practice to have it. Have a less ability to think critically because in learning they still prioritize the process of remembering and memorizing the concepts obtained only from books and teachers. Not accustomed to practicing critical-thinking indicators in learning and still not empowering critical-thinking skills (Agnafia, 2019).

In education, constructivist learning theory not only provides knowledge, but is also able to give the students some opportunities to find and apply their own ideas (Trianto, 2014). The low ability to think critically will adversely affect education. Critical-thinking skills are trained so that students can make a decisions in analyzing their thinking and drawing conclusions appropriately (Nikmah, 2019). Critical-thinking skills can guide the student to decide something and take action on the problems faced and equip them to face every problem encountered in everyday life (Hartini \& Sukardjo, 2015).

The following are the indicators of critical-thinking skills for each geoscience test question that are answered correctly:

Table 6. Percentage of indicators of critical-thinking skills on each geoscience test question.

\begin{tabular}{cccc}
\hline Critical-Thinking Indicator & $\begin{array}{c}\text { Test Question } \\
\text { Number }\end{array}$ & Percentage (\%) & Criteria \\
\hline Interpretation & 3 & 40 & Very Low \\
& 6 & 34 & Very Low \\
& 9 & 30 & Very Low \\
& 11 & 42 & Very Low \\
Analysis & 15 & 70 & Enough \\
& 10 & 68 & Enough \\
& 12 & 29 & Very Low \\
Evaluation & 14 & 54 & Very Low \\
Inferential & 17 & 58 & Low \\
& 13 & 79 & High \\
& 1 & 30 & Very Low \\
Explanation & 8 & 53 & Very Low \\
& 18 & 37 & Very Low \\
& 4 & 50 & Very Low \\
& 7 & 60 & Enough \\
& 16 & 52 & Very Low \\
Self Regulation & 19 & 43 & Very Low \\
& 20 & 65 & Enough \\
& 2 & 31 & Very Low \\
& 5 & 50 & Very Low \\
\hline
\end{tabular}

The acquisition of interpretation indicators with the lowest percentage of students answering correctly, namely $30 \%$, is indicated by test question number 9 , where in this question students categorize mitigation efforts before the earthquake with a total of only 32 students who answered correctly. Almost the same answer resulted in the 
students being wrong in giving their opinion. The difficulty level of the test is also caused by the complexity of the test subject and the condition of the answer choices because tests often present students who are confused and alternative answers that are also homogeneous or sentences that are too difficult to understand (Hanifah, 2014)

The analysis indicator obtained the lowest percentage, namely $29 \%$, which was indicated by the test question number 12 with only 31 students who answered correctly on the question indicator solving the concept of the relationship between air pressure in the atmosphere. This maybe because of the lack of students understanding in terms of molecular relationships in the atmosphere, which so far have only been imagined by abstract thinking. Factors which determine student learning success is the ability to think abstractly (Suliman, et al, 2017). Abstract is a natural process of mind that focuses on some aspects of the state to make decisions and the process of making concrete situations by finding new meanings to build interconnections in various whole elements (Yusepa, et al, 2018)

The evaluation indicator obtained a good percentage, namely $79 \%$ with test question number 13 with the number of students who answered correctly as many as 85 of the total students on the question indicator stated the benefits of volcanoes. Therefore, it can be concluded that students are able to evaluate a question posed in the question. Evaluation ability is the activity of making an assessment with the value of an idea, creation, method or method (Yudhanegara, 2015). In line with the acquisition of critical indicators according to (Nikmah, et al, 2019) who get high scores with sufficient categories on the evaluation indicators.

The inferential indicator obtained the lowest percentage, namely $30 \%$, indicated by the number 1 test question with the number of students who answered correctly as many as 31 on the question indicator to generalize the water cycle. In this case, students feel that they are unable to conclude correctly regarding the images presented. Basic competencies that sometimes become difficult for students are when summarizing news or text content, concluding ideas, finding information from tables or pictures (Wuryani, 2014)

The explanation indicator obtained by the lowest percentage was $43 \%$ which was indicated by the test question number 19 with the number of students who answered correctly as many as 46 of the total students on the indicators identifying the stratosphere layer. Students still do not understand the layers of the earth, resulting in poor learning outcomes in identifying the stratosphere. Atmospheric material is material that requires critical-thinking skills (Mukarromah, et al, 2020). The ability to think critically in earth topics, especially atmsofer, needs to direct students to think in solving environmental problems, provide solutions (Sholihah, et al, 2016)

In the self regulation indicator, the lowest percentage was $31 \%$ which was shown by the number 2 test question with the number of students who answered correctly as many as 33 on the indicator questions self-evaluating against inferential answers about the water cycle. This can happen because students do not understand the water cycle which is only presented in the form of pictures without any direction in answering the questions. The learning outcomes of class X senior high school 1 Mawansangka Tengah show an average value of 64 in the hydrosphere material (Fitriono \&Ramli, 2017)

Based on the results, the analysis obtained by the students, there is a need for mitigation assistance by keeping an eye on the environment, the concept of geoscience is also trained so that it can be used as the basis of future life. Components in geoscience 
that include geoscience knowledge, predictive skills, and decision -making skills will be indispensable to face present and future challenges (Hariyono, 2018).

One way to gain critical-thinking skills such as modifying learning strategies or methods (Nikmah, et al, 2019). Learning models, strategies, methods or learning techniques used must be interactive, inspirational, challenging, fun, motivating, and encouraging student interest in learning (Wijayanti, et al, 2015). The learning method will affect the results and enthusiasm for learning, especially in the ability to think critically, especially in expressing opinions. A learning model that has the potential to improve students' critical-thinking is a model that facilitates interaction between students, such as debates, group discussions, asking open-ended questions, solving problems, evaluating and applying concepts to solve problems in new situations (Agboeze \&Ugwoke, 2013).

\section{CONCLUSIONS}

Based on the result, we can conclude that students are very low in critical-thinking on the concept of geoscience, disasters and their mitigation even though the evaluation indicators are categorized as sufficient. These critical-thinking skills must be trained continuously, especially in geoscience material. The accuracy of the analysis of criticalthinking skills in this research only shows the results in the Mojokerto area, so that further research can be carried out in disaster-prone areas such as coastal areas, mountains, and so on. Further research is also expected to solve the low thinking skills of students by using several efficient models to train or improve critical-thinking skills, especially in relation to global issues.

\section{REFERENCES}

Abdullah, I. (2013). Berpikir kritis matematika. Delta-Pi: Jurnal Matematika dan Pendidikan Matematika, 2(1), 66-75. http://dx.doi.org/10.33387/dpi.v2i1.100

Agboeze, M. U., \& Ugwoke, E. (2013). Enhancement of critical thinking skills of vocational and adult education students for entrepreneurship development in Nigeria. Journal of Education and Practice, 4(17), 116-123.

Agnafia, D. N. (2019). Analisis kemampuan berpikir kritis siswa dalam pembelajaran biologi. Jurnal Biologi dan Pembelajarannya, 6(1), 45-53. http:// doi.org/10.25273/florea.v6i1.4369

Anggrayini, S. \& Hariyono, Eko. (2020). The students's voice of volcanology in education for sustainable development context. IOP Conf. Series :Journal of Physics: Conference Series. https://iopscience.iop.org/article/10.1088/1742-6596/1491/1/012032

Arifin, Z. (2017). Kriteria instrumen dalam suatu penelitian. Jurnal THEOREMS (The Original Research of Mathematics), 2(1), 28-36. http:/ / dx.doi.org/10.31949/th.v2i1.571

Arikunto, S. (2013). Dasar-dasar evaluasi pendidikan Edisi 2. Jakarta : PT Bumi Aksara

Astutik, S., Susanti, E., Madlazim \& Nur, M. (2017). Effectiveness of collaborative students worksheet to improve students affective scientific collaborative and science process skills (SPS). International Journal of Education and Research, 5(1), 151-164.

Azmi, D. T. U., Astutik, S., \& Subiki. (2020). Pengaruh model pembelajaran Collaborative Creativity (CC) berbasis scaffolding terhadap kemampuan scientific reasoning fisika siswa SMA. Jurnal Penelitian Pendidikan Sains, https:/ / dx.doi.org/10.26740/jpps.v10n1.p1833-1843

Baruah, J. \& Paulus, P. B. (2019). Collaborative creativity and innovation in education. Springer Nature Switzerland (pp. 155-177). 
Encisco, O. L. U., Diana, S. U. E., \& Maria del Pilar, V. D.. (2017). Critical thinking and its importance in education : Some Reflection. Semantic Scholar, 19(34), 79-89. doi : $10.16925 /$ ra.v19i34.2144

Ennis, R.H. (2011). The nature of critical thinking : An outline of critical thinking dispositions and abilities. Chicago : University of Illinois.

Facione, P. A. (2011). Critical thinking: What it is and why it counts. California : The California Academic Press.

Fitriono \& Ramli. (2017). Perbedaan hasil belajar geografi antara siswa yang diajar dengan menggunakan model pembelajaran kooperatif tipe jigsaw dengan kooperatif tipe group investigation pada materi hidrosfer kelas X SMA Negeri 1 Mawasangka Tengah. Jurnal Penelitian Pendidikan Geografi, 1(1), 1-16. http://dx.doi.org/10.36709/jppg.v1i1.2424

Frederick, R. (2013). Encouraging critical thinking in distance learning: Ensuring challenging intellectual programs. Information Age Publishing, 10(1). https:/ / www.infoagepub.com/products/distance-learning-10-1-2013

Fuad, N. M., Zubaidah, S., Mahanal, S. \& Suarsini, E. (2017). Improving junior high schools' critical thinking skills based on test three different models of learning. International Journal of Instruction, 10(1), 101-116. https:/ / eric.ed.gov/ ?id=EJ1125163

Guo, Z. (2016). The cultivation of $4 C^{\prime}$ s in China critical thinking, communication. International Conference on Education, Management and Applied Social Science.

Gormley \& William. (2017). The critical advantage : Developing critical thinking skills in school. America: Harvard Education Press.

Hanifah, N. (2014). Perbandingan tingkat kesukaran, daya pembeda butir tes dan reliabilitas tes untuk bentuk pilihan ganda biasa dan pilihan ganda asosiasi mata pelajaran ekonomi. Sosio e-KONS, 6(1), 41-55. http:/ / dx.doi.org/10.30998/sosioekons.v6i1.1715

Hariyono, E., Liliasari, Tjasyono, \& Madlazim. (2016). Volcanic eruption crisis and the challengesof geoscience education in Indonesia. In : Proceedings of International Seminar on Mathematics, Science, and Computer Science Education, 1708, 080001-080004 https:/ / doi.org/10.1063/1.4941190

Hariyono, E. (2018). Pengembangan volcano learning project (VLP) dalam pembelajaran geosains bagi mahasiswa calon guru fisika. SemanticScholar

Hartini \& Sukarjo. (2015). Pengembangan higher order thinking multiple choice test untuk mengukur keterampilan berpikir kritis IPA kelas VII SMP/MTs. Jurnal Inovasi Pendidikan IPA, 1 (1), 86-101. https:// doi.org/10.21831/jipi.v1i1.4535

Kallesta, Karmila \& Erfan. (2017). Analisis faktor penyebab kesulitan belajar IPA fisika pada materi bunyi. Jurnal Pendidikan Fisikia. 1 (1). https:// doi.org/10.31227/osf.io/dwh5e

Karakoç, M. (2016). The significance of critical thinking ability in terms of education. International Journal of Humanities and Social Science, 6(7), 81-84.

Kusairi, S. (2013). Asesmen Pembelajaran Sains. Malang : UM Press

Mabruroh \& Suhandi. (2017). Construction of critical thinking skills test instrument related the concept on sound wave. IOP Conf. Series :Journal of Physics: Conference Series. doi:10.1088/1742-6596/812/1/012056

Masni, S. E., N, F. L., \& Wulandari, S. (2020). Increasing critical thinking ability of students through guided inquiry model in learning photosynthetic materials in SMA PGRI Pekanbaru. Journal of Educational Sciences, 4(2), 285-295.

Mukarromah, Mar'atul, Budijanto, \& Dwiyono. (2020). Pengaruh model challenge based learning terhadap kemampuan berpikir kritis siswa SMA pada materi perubahan iklim. Jurnal Pendidikan, 5(2), 214-218. http://dx.doi.org/10.17977/jptpp.v5i2.13176

Murawski, Linda M. (2014). Critical thinking in the classroom and beyond. Eric Journal of Learning in Higher Education, 10(1), 25-30.

Nikmah, Dewi, Linda, \& Desi. (2019). Menyiapkan guru IPA masa depan menghadapi trsnformasi dunia digital. Seminar Nasional Pendidikan Sains. 179-185. 
Nurdyanto, Hendra, Sifak, \& Rudiana. (2017). Pengaruh penerapan model pembelajaran kooperatif tipe nht dengan pendekatan Spices Continuing terhadap keterampilan berpikir kritis dan hasil belajar siswa SMP. Jurnal Penelitian Pendidikan IPA, 2(2), 58-65. http://dx.doi.org/10.26740/jppipa.v2n2.p58-65

Nuryanti, Siti, \& Markus. (2018). Analisis kemampuan berpikir kritis siswa. Jurnal Pendidikan, 3(2), 155-158. http://dx.doi.org/10.17977/jptpp.v3i2.10490

Oktanin, Wika \& Sukirno. (2015). Analisis butir soal ujian akhir mata pelajaran ekonomi akuntansi. Jurnal Pendidikan Akuntansi Indonesia, 13 (1), 35-44. https://doi.org/10.21831/jpai.v13i1.5183

Paskalin, G., \& Susanti. (2020). Item analysis og force material problem in elementary school. Jurnal Pendidikan Sekolah Dasar, 3(2), 23-34. https://doi.org/10.21831/didaktika.v3i1.31431

Permendikbud. (2016). Panduan penilaian untuk sekolah menegah. Direktorat Pembinaan Pendidikan Dasar Pertama. Jakarta : Ditjen Dikdasmen Kemendikbud.

Permendikbud. (2016). Peraturan menteri pendidikan dan kebudayaan republik Indonesia no. 20 tahun 2016 tentang standar kompetensi lulusan pendidikan dasar dan menengah. Jakarta : Menteri Pendidikan Republik Indonesia

Permenkes. (2014). Penilaian kerusakan, kerugian, dan kebutuhan sumber daya kesehatan pasca bencana. Jakarta : Menteri Kesehatan Republik Indonesia

Puspita, et al. (2017). Analysis of critical thinking skills on the topic of static fluid. IOP Conf. Series :Journal of Physics:Conference Series. doi :10.1088/1742-6596/895/1/012100

Rahayu, S. D., Ashadi, \& Dwiastuti, S. (2020). Analysis of students' critical thinking skills in secondary schools on plants' structure and functions material. 3rd International Conference on Learning Innovation and Quality Education (ICLIQE 2019) Analysis. 397, 1060-1065. https://doi.org/10.2991/assehr.k.200129.131

Riduwan. (2014). Dasar-dasar Statistika. Bandung: Alfabeta.

Rimiene, Vaiva. (2015). Assessing and developing students' critical thinking. Sage Journal, 2, 1722.

Sarjono. (2017). Internalisasi berpikir kritis dalam pembelajaran fisika. Jurnal Madaniyah. 7 (2). 343-353.

Seventika, S.Y, Y.L Sukestiyarno, \& Scolastika Mariani. 2017. Critical thinking analysis based on facione (2015) - angelo (1995) logical mathematics material of vocational high school (VHS). IOP Conf. Series :Journal of Physics:Conference Series. doi :10.1088/1742-6596/983/1/012067

Shi, W.Z., He. X., Wang, Y., Fan Z.G. \& Guo L. (2016). PISA and TIMSS science score, which clock is more accurate to indicate national science and technology competitiveness. Eurasia Journal of Mathematics, Science \& Technology Education, 12(4), 965-974. https://doi.org/10.12973/eurasia.2016.1239a

Sholihah, M., Utaya, S., \& Susilo, S. (2016). Pengaruh model experiential learning terhadap kemampuan berpikir siswa SMA. Jurnal Pendidikan: Teori, Penelitian, dan Pengembangan, 1(11), 2096 - 2100. http:/ / dx.doi.org/10.17977/jp.v1i11.7869

Sudijono, A. (2017). Pengantar statistik pendidikan. Jakarta: PT Raja Grafindo Persada.

Sugiyono. (2015). Metode penelitian $\mathcal{E}$ pengembangan (research and development). Bandung: Alfabeta.

Suliman, Sarwanto, \& Suparmi. (2017). Pendekatan saintifik pada pembelajaran fisika dengan metode eksperimen dan demonstrasi ditinjau dari kemampuan berpikir abstrak dan kemampuan analisis siswa. Jurnal Inkuiri, 6(1), 21-30. https://doi.org/10.20961/inkuiri.v6i1.17260

Sujarweni, V., Wiratna \& Poly Endrayanto. (2011). Statistika untuk penelitian. Yogyakarta : Graha Ilmu.

Sukmadinata, N. (2015). Metode penelitian pendidikan. Remaja Rosdakarya : Bandung.

Trianto. (2014). Mendesain model pembelajaran model pembelajaran inovatif, progresif, dan kontestual. Jakarta : Prenadamedia Group. 
Utomo, B. (2018). Analisis validitas isi butir soal sebagai salah satu upaya peningkatan kualitas pembelajaran di madrasah berbasis nilai-nilai islam. Jurnal Pendidikan Matematika, 1(2). 145 - 159. http://dx.doi.org/10.21043/jpm.v1i2.4883

Wegerif, R. (2010). Mind expanding: Teaching for thinking and creativity in primary education. Berkshire: Mc Graw Hill Education.

Widoyoko, E. (2017). Teknik penyusunan instrumen penelitian. Yogyakarta: Pustaka Pelajar.

Wijaya, Etistika Yuni, Dwi Agus S., Amat Nyoto. 2016. Transformasi pendidikan abad 21 sebagai tuntutan pengembangan sumber daya manusia di era global. Prosiding Seminar Nasional Pendidikan Matematika 2016. Malang : Universitas Kanjuruhan Malang

Wijaya, I \& Darmayanti. (2019). Analisis butir soal ujian akhir semester mata kuliah mapel sd matematika i tahun akademik 2018/2019. Jurnal Pendidikan Dasar, 7 (1). http://doi.org/10.18592/tarbiyah.v7i1.2100

Wijayanti, et al. (2015). Analisis Kemampuan Berpikir Kritis Siswa Kelas V dalam Pembelajaran IPA di 3 SD Gugus X Kecamatan Buleleng. E-Jurnal PGSD Universitas Pendidikan Ganesha. 3 (1), 1-12.

Wuryani, et al. (2014). Peningkatan kemampuan siswa membuat kesimpulan dari informasi yang didengar melalui metode inkuiri. Jurnal Manajemen Pendidikan, 9(1), 40-48.

Yudhanegara dan Lestari. (2015). Penelitian Pendidikan Matematika. Bandung : Refika Aditama

Yuliati, L. (2013). Efektivitas bahan ajar IPA terpadu terhadap kemampuan berpikir tingkat tinggi siswa SMP. Jurnal Pendidikan Fisika Indonesia, 9(1), 55-57. http:/ /dx.doi.org/10.15294/jpfi.v9i1.2580.

Yusepa, et al. (2018). Promoting middle school students' abstract-thinking ability through cognitive apprenticeship instruction in mathematics learning. IOP Conf. Series :Journal of Physics:Conference Series. doi :10.1088/1742-6596/948/1/012051

Zubaidah, S., Corebima, A. D., dan Mistianah. (2015). Asesmen berpikir kritis terintegrasi tes essay. Proceeding Symposium on Biology Education (Symbion). Jogjakarta: Universitas Ahmad Dahlan.

\footnotetext{
*Anggraeni Rusmia Putri, S.Pd. (Corresponding Author)

Postgraduate Programe, Continuing Program Development

State University of Surabaya,

Jl. Lidah Wetan, Surabaya, East Java, 60213, Indonesia

Email: anggraeni.19045@mhs.unesa.ac.id
}

\section{Dr. Eko Hariyono, S.Pd., M.Pd.}

Postgraduate Programe, Continuing Program Development

State University of Surabaya,

J1. Lidah Wetan, Surabaya, East Java, 60213, Indonesia

Email: ekohariyono@unesa.ac.id

Prof. Dr. Erman, M.Pd.

Postgraduate Programe, Continuing Program Development

State University of Surabaya,

Jl. Lidah Wetan, Surabaya, East Java, 60213, Indonesia

Email: erman@unesa.ac.id 